\title{
UPAYA MENINGKATKAN DAYA INGAT SISWA DI MASA PANDEMI COVID-19 MELALUI PENERAPAN MODEL PEMBELAJARAN TAKE AND GIVE PADA SUBTEMA PERISTIWA KEBANGSAAN MASA PENJAJAHAN KELAS V SD N DONOTIRTO KASIHAN BANTUL YOGYAKARTA
}

\author{
IIma Fahmia Nugraheni ${ }^{1}$, Dhiniaty Gularso ${ }^{2}$ \\ ${ }^{1}$ Universitas PGRI Yoyakarta \\ Email: ilmafahmian@gmail.com \\ ${ }^{2}$ Universitas PGRI Yoyakarta \\ Email: dhiniaty@upy.ac.id
}

\begin{abstract}
Abstrak
Penelitian ini bertujuan untuk meningkatkan daya ingat siswa di masa pandemi covid-19 melalui penerapan model pembelajaran take and give pada subtema Peristiwa Kebangsaan Masa Penjajahan kelas V SD N Donotirto Kasihan Bantul Yogyakarta. Penelitian ini merupakan penelitian tindakan kelas (PTK). Subjek penelitian ini adalah 9 siswa dari total 24 siswa kelas V SD N Donotirto tahun ajaran 2020/2021 yang diizinkan untuk berpartisipasi dalam penelitian berdasarkan surat dari Kepala SD N Donotirto Nomor: 25/SD. DNT/Kshn/X/2020 dikarenakan untuk mengantisipasi penyebaran virus covid-19 dengan meminimalkan kerumunan siswa. Objek dalam penlitian ini adalah daya ingat siswa. Teknik pengumpulan data dilakukan melalui observasi, wawancara tak berstruktur dan tes. Teknik analisis data deskriptif kuantitatif dengan menghitung persentase dan rata-rata skor.

Hasil penelitian menunjukkan pada kondisi awal daya ingat siswa diperoleh hasil rata-rata persentase $26,7 \%$ dengan kriteria kurang dan hasil observasi kegiatan mengajar guru dengan persentase $80 \%$ dengan kriteria baik. Setelah dilakukan tindakan pada siklus I, peningkatan daya ingat siswa diperoleh hasil rata-rata persentase $46,65 \%$ dengan kriteria cukup dan hasil observasi kegiatan mengajar guru dengan rata-rata persentase $98 \%$ dengan kriteria sangat baik. Penelitian ini dihentikan sampai siklus II karena telah mencapai indikator keberhasilan dengan diperoleh hasil rata-rata persentase daya ingat siswa sebanyak $81,1 \%$ dengan kriteria sangat baik dan diperoleh hasil observasi kegiatan mengajar guru dengan hasil rata-rata persentase 100\% dengan kriteria sangat baik. Dengan demikian dapat disimpulkan bahwa penggunaan model pembelajaran take and give dapat meningkatkan daya ingat siswa.
\end{abstract}

Kata kunci: penelitian tindakan kelas, masa pandemi covid-19, daya ingat, model pembelajaran take and give.

\begin{abstract}
This study aims to improve students' memory during the Covid-19 pandemic through the application of the take and give learning model in the sub-theme national events during the colonial period of the fifth grade at SD N Donotirto Kasihan Bantul Yogyakarta. This research is a classroom action research. The subjects of this research is 9 students from a total of 24 fifth grade students at $S D$ $N$ Donotirto in the academic year of 2020/2021 which was allowed to participate in the research based on a letter from the principal of $S D N$ Donotirto Number : 25/SD. DNT/Kshn/X/2020 due to anticipating the spread of the Covid-19 virus by minimizing the crowd of students. The object of this research is students' memory. Data collection techniques are carried out through observation, unstructured interviews and tests. The technique of quantitative descriptive data analysis was done by calculating the percentage and average score.

The results of this research showed that in the initial condition, the students' memory was obtained an average percentage of $26.7 \%$ with poor criteria and the results of observations of teaching activities with a percentage of $80 \%$ with good criteria. After taking action in cycle I, the improvement of students memory obtained an average result of $46.65 \%$ with sufficient criteria and the results of observations of teaching activities with an average percentage of $98 \%$ with very
\end{abstract}


good criteria. This research was stopped until cycle II because it has achieved indicators of success with the average result of students' memory as much as $81.1 \%$ with very good criteria and the results of observations of teaching activities with an average result of $100 \%$ with very good criteria. Thus it can be concluded that the use of the take and give learning model can improve students memory.

Keywords: classroom action research, during the covid-19 pandemic, memory, take and give learning model.

\section{PENDAHULUAN}

Menurut UU RI tentang Sistem Pendidikan Nasional No. 20 tahun 2003 pendidikan adalah usaha sadar dan terencana untuk mewujudkan suasana belajar dan proses pembelajaran agar siswa secara aktif mengembangkan potensi dirinya untuk memiliki kekuatan spiritual keagamaan, pengendalian diri, kepribadian, kecerdasan, akhlak mulia, serta keterampilan yang diperlukan dirinya dan masyarakat. Pendidikan pada jenjang Sekolah Dasar dimulai dari kelas I sampai kelas VI. Karakteristik siswa dibagi menjadi dua kelompok yaitu kelas rendah I sampai III dan kelas tinggi IV sampai VI. Dalam pendidikan peran seorang guru sangatlah penting, guru harus memiliki kemampuan untuk mewujudkan tujuan pendidikan nasional sebagaimana yang telah dicantumkan dalam UU RI tentang Sistem Pendidikan Nasional pasal 3 No. 20 tahun 2003 sebagai berikut: "Pendidikan nasional berfungsi mengembangkan kemampuan dan membetukan watak serta peradaban bangsa yang bermartabat dalam rangka mencerdaskan kehidupan bangsa, bertujuan untuk tumbuh kembang potensi anak agar menjadi manusia yang beriman dan bertaqwa kepada Tuhan Yang Maha Esa, berakhlak mulia, sehat, berilmu, cakap, kreatif, mandiri dan menjadi warga negara yang demokratis serta bertanggung jawab. "Oleh karena itu, seorang guru harus mampu mewujudkan tujuan pendidikan seperti yang telah di cantumkan dalam UndangUndang.

Menurut Fatoni dan Gularso (2017:3) upaya yang bisa dilakukan untuk meningkatkan mutu pendidikan di sekolah yaitu dengan melakukan perbaikan pada proses pembelajaran. Seorang guru harus mempunyai kemampuan mendesain program pembelajaran, memiliki keterampilan memilih, serta dapat menggunakan berbagai model dan metode mengajar untuk diterapkan dalam pembelajaran yang efektif. Oleh sebab itu, seorang guru memiliki peran penting dalam proses belajar dan mengajar. Seorang guru harus mampu menciptakan suasana pembelajaran yang baik dan menyenangkan sehingga dapat membantu siswa dalam memahami suatu materi pembelajaran. Pembelajaran yang baik dan menyenangkan ini akan memberi kesan bagi siswa dan akan diingat dalam ingatan siswa. Untuk mewujudkan tujuan pendidikan, dalam proses pembelajaran guru harus menggunakan strategi, metode, model dan media pembelajaran yang sesuai dengan perkembangan siswa serta dapat menarik perhatian siswa.

Keberhasilan proses pembelajaran tentunya tidak lepas dari guru sebagai sumber belajar. Tugas seorang guru sebagai pendidik bukanlah tugas yang mudah. Guru harus memahami 
karakteristik tiap siswa dengan melakukan pendekatan-pendekatan kepada siswa. Dengan begitu guru dapat memahami dan mengenali karakter masing-masing siswa. Guru harus kreatif dalam menciptakan suasana belajar yang menyenangkan agar dapat menarik perhatian siswa. Untuk menciptakan suasana belajar yang menyenangkan guru dapat menggunakan model pembelajaran yang sesuai dengan kondisi siswa agar tujuan pembelajaran dapat tercapai secara maksimal.

Malawi, dkk (2019:1-2) berpendapat bahwa pembelajaran terpadu merupakan suatu konsep pendekatan pembelajaran yang melibatkan beberapa mata pelajaran untuk memberikan pengalaman belajar yang bermakna bagi peserta didik. Pembelajaran terpadu diyakini sebagai pendekatan yang berorientasi pada praktek pembelajaran yang sesuai dengan kebutuhan peserta didik. Pembelajaran terpadu dapat membantu menciptakan kesempatan yang luas bagi peserta didik untuk melihat dan membangun konsep-konsep yang saling berkaitan. Pembelajaran terpadu merupakan model pembelajaran yang menggunakan tema untuk mengaitkan beberapa mata pelajaran sehingga dapat memberikan pengalaman bermakna bagi peserta didik. Pendidikan terpadu didefinisikan sebagai pembelajaran yang menghubungkan berbagai gagasan, konsep, keterampilan, sikap dan nilai, baik antar mata pelajaran maupun dalam satu mata pelajaran. Pembelajaran terpadu memberi penekanan pada pemilihan suatu tema yang spesifik yang sesuai dengan materi pelajaran, untuk mengajar satu atau beberapa konsep yang memadukan berbagai informasi.
Pada pembelajaran terpadu melibatkan antara beberapa mata pelajaran yang membentuk suatu tema dan subtema tertentu. Biasanya dalam satu tema terbagi menjadi tiga subtema yang didalam tiap subtema terbagi menjadi enam pembelajaran. Salah satu tema pada pembelajaran terpadu kelas $\mathrm{V}$ yaitu tema Peristiwa dalam Kehidupan yang didalamnya terbagi lagi menjadi beberapa subtema. Salah satunya subtema Peristiwa Kebangsaan Masa Penjajahan. Pada subtema tersebut didalamnya membahas tentang berbagai peristiwa penting yang terjadi pada masa penjajahan di Indonesia yang mencakup beberapa kejadian, tanggal penting, nama tempat dan nama tokoh.

Berdasarkan hasil wawancara pada Sabtu, 26 September 2020 pukul 08.00 WIB di kelas V SD N Donotirto, dalam kegiatan pembelajaran guru masih sering menggunakan metode ceramah yang cenderung menggunakan pembelajaran satu arah yang berpusat pada guru (teacher centered) tanpa menggunakan model pembelajaran lain, serta dalam kegiatan pembelajaran guru jarang menggunakan berbagai media pembelajaran dikarenakan adanya keterbatasan waktu dalam menyiapkan media pembelajaran. Selain itu, guru juga menyampaikan tentang rendahnya daya ingat siswa pada subtema Peristiwa Kebangsaan Masa Penjajahan. Hal ini terbukti dari hasil evaluasi pada subtema Peristiwa Kebangsaan Masa Penjajahan siswa kelas $\mathrm{V}$ yang dilihat dengan menggunakan rubrik penilaian daya ingat sebagai berikut: 
Tabel 1. Hasil Evaluasi Pra Tindakan

\begin{tabular}{|c|c|c|c|c|}
\hline Variabel & Deskripsi & Skor & Kriteria & $\begin{array}{c}\text { Jumlah } \\
\text { Siswa }\end{array}$ \\
\hline \multirow[t]{5}{*}{$\begin{array}{l}\text { Daya } \\
\text { Ingat }\end{array}$} & $\begin{array}{l}\text { Apabila anak dapat } \\
\text { mengisi } 10 \text { soal esai } \\
\text { pada lembar evaluasi } \\
\text { dengan benar. }\end{array}$ & 5 & $\begin{array}{l}\text { Sangat } \\
\text { Tinggi }\end{array}$ & 0 \\
\hline & $\begin{array}{l}\text { Apabila anak dapat } \\
\text { mengisi } 8-9 \text { soal esai } \\
\text { pada lembar evaluasi } \\
\text { dengan benar. }\end{array}$ & 4 & Tinggi & 0 \\
\hline & $\begin{array}{l}\text { Apabila anak dapat } \\
\text { mengisi } 6-7 \text { soal esai } \\
\text { pada lembar evaluasi } \\
\text { dengan benar. }\end{array}$ & 3 & Sedang & 0 \\
\hline & $\begin{array}{l}\text { Apabila anak dapat } \\
\text { mengisi } 4-5 \text { soal esai } \\
\text { pada lembar evaluasi } \\
\text { dengan benar. }\end{array}$ & 2 & Kurang & 3 \\
\hline & $\begin{array}{l}\text { Apabila anak dapat } \\
\text { mengisi } 1-3 \text { soal esai } \\
\text { pada lembar evaluasi } \\
\text { dengan benar. }\end{array}$ & 1 & $\begin{array}{l}\text { Sangat } \\
\text { Kurang }\end{array}$ & 6 \\
\hline
\end{tabular}

Tabel 1. menunjukkan hasil evaluasi pada Subtema Peristiwa Kebangsaan Masa Penjajahan siswa kelas $\mathrm{V}$, dari 9 orang siswa tidak ada siswa yang dapat mengisi 6-10 soal esai pada lembar evaluasi dengan benar, 3 siswa dapat mengisi 4-5 soal esai pada lembar evaluasi dengan benar, serta 6 siswa dapat mengisi 1-3 soal esai pada lembar evaluasi dengan benar. Berdasarkan data tersebut dapat diketahui rata-rata perolehan nilai evaluasi pada subtema Peristiwa Kebangsaan Masa Penjajahan siswa kelas $\mathrm{V}$ yang dinilai dengan menggunakan rubrik penilaian daya ingat dengan tingkat keberhasilan $26,7 \%$. Pencapaian tersebut termasuk dalam kriteria kurang.

Berdasarkan hasil observasi pembelajaran tematik pada Sabtu, 26 September 2020 pukul 08.35-09.35 WIB di kelas V SD N Donotirto, dalam kegiatan pembelajaran guru hanya menerapkan metode ceramah tanpa menggunakan model pembelajaran lain yang melibatkan siswa untuk aktif dalam melaksanakan kegiatan pembelajaran, melibatkan siswa untuk bekerja sama dengan siswa lain, serta membangun suasana belajar yang aktif dan menyenangkan. Pada kegiatan pembelajaran guru hanya menggunkan buku tematik sebagai sumber belajar siswa. Selama kegiatan observasi di kelas $\mathrm{V}$, terdapat beberapa siswa yang tidak memperhatikan guru ketika pembelajaran sedang berlangsung, hal tersebut disebabkan karena guru hanya menggunakan metode ceramah tanpa menggunakan media pembelajaran dan model pembelajaran yang dapat menarik perhatian siswa. Selain itu, terdapat beberapa siswa yang sulit untuk mengingat materi yang disampaikan guru karena guru hanya menggunkan metode ceramah tanpa menggunakan model pembelajaran yang dapat meningkatkan daya ingat siswa terhadap suatu materi pembelajaran. Hal tersebut dibuktikan dengan beberapa siswa tidak mampu menjawab pertanyaan yang diberikan guru mengenai materi yang baru saja dijelaskan dengan benar tanpa melihat buku serta rendahnya hasil nilai prestasi belajar siswa. Terlebih pada subtema Peristiwa Kebangsaan Masa Penjajahan yang didalamnya banyak membahas tentang berbagai peristiwa penting yang terjadi pada masa penjajahan di Indonesia yang mencakup beberapa kejadian, tanggal penting, nama tempat dan nama tokoh yang seharusnya dapat dipahami dan diingat oleh siswa. Tidak hanya diingat pada saat pembelajaran berlangsung, melainkan dapat diingat ketika pembelajaran telah selesai. Selain itu, peneliti juga melakukan observasi dengan berpedoman pada lembar observasi kegiatan mengajar guru sebelum tindakan. Dari hasil observasi kegiatan mengajar guru sebelum tindakan terdapat 5 aspek yang tidak 
dilakukan oleh guru dalam pembelajaran. 5 aspek tersebut adalah menggunakan model pembelajaran yang melibatkan siswa untuk aktif dalam pembelajaran, menggunakan model pembelajaran yang melibatkan siswa untuk bekerja sama dengan siswa lain, menggunakan model pembelajaran yang membangun suasana kelas aktif dan menyenangkan, menggunakan berbagai sumber belajar dan memfasilitasi siswa membuat rangkuman. Berdasarkan hasil observasi kegiatan mengajar guru sebelum tindakan mencapai tingkat keberhasilan $80 \%$. Pencapaian tersebut termasuk dalam kriteria baik.

Untuk meningkatkan daya ingat siswa tentang suatu materi pembelajaran dapat dilakukan dengan mengadakan perubahan-perubahan dalam pelaksanaan proses pembelajaran. Oleh karena itu perlu dirancang suatu model pembelajaran yang menarik serta dapat meningkatkan daya ingat siswa terhadap suatu materi pembelajaran. Dengan peningkatan daya ingat siswa, maka prestasi belajar siswa juga akan menigkat. Salah satu model pembelajaran yang bisa dipilih sebagai alternatif solusi dalam masalah di atas adalah dengan menggunakan model pembelajaran take and give. Menurut Hartami, dkk (2014:171) dengan memberikan pembelajaran yang aktif seperti tipe take and give dapat membantu ingatan siswa sehingga dapat dihantarkan kepada tujuan pembelajaran dengan sukses. Selain itu model pembelajaran tipe take and give merupakan suatu tipe pembelajaran yang mengajak siswa untuk saling berbagi mengenai materi yang disampaikan oleh guru dengan kata lain tipe ini melatih siswa terlibat secara aktif dalam menyampaikan materi yang mereka terima ke siswa lain secara berulang-ulang dengan tujuan untuk membangun suasana belajar yang dinamis, penuh semangat dan antusiasme serta menciptakan suasana belajar dari pasif ke aktif, dari jenuh menjadi riang, serta mempermudah siswa dalam mengingat materi. Menurut Huda (Prihastin, 2016:12) model pembelajaran take and give dapat diartikan sebagai model pembelajaran saling memberi dan saling menerima. Prinsip tersebut menjadi intisari dari model pembelajaran take and give. Take and give merupakan model pembelajaran yang didukung oleh penyajian data yang diawali dengan pemberian kartu kepada siswa, di dalam kartu terdapat catatan yang harus dikuasai atau dihafal oleh masingmasing siswa. Siswa kemudian diminta untuk mencari pasangan untuk bertukar pengetahuan sesuai dengan apa yang didapatkannya dikartu, kemudian kegiatan pembelajaran diakhiri dengan melakukan evaluasi kepada siswa dengan menanyakan pengetahuan yang dimiliki dan diterima siswa dari pasangannya. Komponen penting dalam model pembelajaran take and give adalah penugasan materi melalui kartu, keterampilan bekerja berpasangan dan berbagi informasi, serta evaluasi yang bertujuan untuk mengetahui pemahaman atau penguasaan siswa terhadap materi yang diberikan di dalam kartu pasangannya.

Berdasarkan permasalahan tersebut, maka peneliti tertarik untuk melakukan penelitian dengan judul "Upaya Meningkatkan Daya Ingat Siswa di Masa Pandemi Covid-19 Melalui Penerapan Model Pembelajaran Take and Give 
pada Subtema Peristiwa Kebangsaan Masa Penjajahan Kelas V SD N Donotirto".

\section{METODE PENELITIAN}

Penelitian ini dilakukan dengan menggunakan Penelitian Tindakan Kelas (PTK) yang lazim dikenal dengan Classroom action research. Penelitian ini dilakukan secara kolaboratif antara guru kelas dengan peneliti. Guru kelas sebagai kolaborator yang sekaligus mengajar di dalam kelas dan mahasiswa sebagai peneliti. Kolaborasi diwujudkan untuk menyamakan pemahaman, kesepakatan tentang permasalahan, pengambilan keputusan dalam menentukan tindakan yang bertujuan untuk meningkatkan daya ingat siswa pada subtema Peristiwa Kebangsaan Masa Penjajahan.

Prosedur penelitian yang dilaksanakan dalam penelitian ini mengacu pada desain penelitian yang dikemukakan oleh Kemmis dan Mc. Taggart yaitu bentuk siklus, setiap siklus terdiri dari dua pertemuan. Pada akhir pertemuan diharapkan tercapainya tujuan yang ingin dicapai yaitu meningkatkan daya ingat siswa pada subtema Peristiwa Kebangsaan Masa Penjajahan. Menurut Kemmis dan Mc. Taggart (Fajri, 2018:105) secara ringkas, tahapan penelitian tindakan menggunakan model spiral terdiri atas 4 langkah, antara lain perencanaan, pelaksanaan/tindakan, observasi dan refleksi.
HASIL DAN PEMBAHASAN

1. Pra Siklus

Tabel 2. Hasil Pencapaian Daya Ingat Siswa Pra Tindakan

\begin{tabular}{|c|c|c|c|c|}
\hline Nama & $\begin{array}{c}\text { Jumlah } \\
\text { Jawaban } \\
\text { Benar }\end{array}$ & Skor & Persentase & Kriteria \\
\hline $\mathrm{Gl}$ & 5 & 2 & $40 \%$ & Kurang \\
\hline $\mathrm{Va}$ & 3 & 1 & $20 \%$ & Sangat Kurang \\
\hline $\mathrm{Ai}$ & 1 & 1 & $20 \%$ & Sangat Kurang \\
\hline $\mathrm{Qi}$ & 3 & 1 & $20 \%$ & Sangat Kurang \\
\hline $\mathrm{Ni}$ & 4 & 2 & $40 \%$ & Kurang \\
\hline $\mathrm{Na}$ & 4 & 2 & $40 \%$ & Kurang \\
\hline $\mathrm{Ca}$ & 1 & 1 & $20 \%$ & Sangat Kurang \\
\hline $\mathrm{Sy}$ & 1 & 1 & $20 \%$ & Sangat Kurang \\
\hline $\mathrm{Fa}$ & 2 & 1 & $20 \%$ & Kurang \\
\hline Jumlah & 24 & 12 & $26,7 \%$ & \\
\hline
\end{tabular}

Dari tabel di atas dapat dilihat bahwa daya ingat siswa kelas $\mathrm{V}$ SD N Donotirto yang berjumlah 9 siswa belum optimal. Berdasarkan data tersebut dapat diketahui rata-rata perolehan nilai evaluasi pada subtema Peristiwa Kebangsaan Masa Penjajahan siswa kelas $\mathrm{V}$ sebelum tindakan yang dinilai dengan menggunakan rubrik penilaian daya ingat dengan tingkat keberhasilan $26,7 \%$. Pencapaian tersebut termasuk dalam kriteria kurang.

Berdasarkan hasil observasi kegiatan mengajar guru sebelum tindakan terdapat 5 aspek yang tidak dilakukan oleh guru dalam pembelajaran. 5 aspek tersebut adalah menggunakan model pembelajaran yang melibatkan siswa untuk aktif dalam pembelajaran, menggunakan model pembelajaran yang melibatkan siswa untuk bekerja sama dengan siswa lain, menggunakan model pembelajaran yang membangun suasana kelas aktif dan menyenangkan, menggunakan berbagai sumber belajar dan memfasilitasi siswa membuat 
rangkuman. Berdasarkan hasil observasi kegiatan mengajar guru sebelum tindakan tersebut mencapai tingkat keberhasilan $80 \%$. Pencapaian tersebut termasuk dalam kriteria baik.

\section{Siklus I}

\section{Pertemuan Pertama}

Tabel 3. Hasil Pencapaian Daya Ingat Siswa Siklus I Pertemuan Pertama

\begin{tabular}{|c|c|c|c|c|}
\hline Nama & $\begin{array}{c}\text { Jumlah } \\
\text { Jawaban } \\
\text { Benar }\end{array}$ & Skor & Persentase & Kriteria \\
\hline Gl & 6 & 3 & $60 \%$ & Sedang \\
\hline $\mathrm{Va}$ & 6 & 3 & $60 \%$ & Sedang \\
\hline $\mathrm{Ai}$ & 3 & 1 & $20 \%$ & Sangat Kurang \\
\hline Qi & 4 & 2 & $40 \%$ & Kurang \\
\hline $\mathrm{Ni}$ & 5 & 2 & $40 \%$ & Kurang \\
\hline $\mathrm{Na}$ & 7 & 3 & $60 \%$ & Sedang \\
\hline $\mathrm{Ca}$ & 2 & 1 & $20 \%$ & Sangat Kurang \\
\hline Sy & 4 & 2 & $40 \%$ & Kurang \\
\hline $\mathrm{Fa}$ & 4 & 2 & $40 \%$ & Kurang \\
\hline Jumlah & 41 & 19 & $42,2 \%$ & Cukup \\
\hline
\end{tabular}

Dari tabel di atas dapat diketahui rata-rata perolehan nilai evaluasi pada subtema Peristiwa Kebangsaan Masa Penjajahan siswa kelas $\mathrm{V}$ siklus I pertemuan pertama yang dinilai dengan menggunakan rubrik penilaian daya ingat mencapai $42,2 \%$. Pencapaian tersebut termasuk dalam kriteria cukup.

Berdasarkan hasil observasi kegiatan mengajar guru pada siklus I pertemuan pertama terdapat 1 aspek kegiatan yang tidak dilakukan oleh guru dalam pembelajaran. Aspek tersebut adalah memfasilitasi siswa membuat rangkuman. Berdasarkan hasil observasi kegiatan mengajar guru siklus I pertemuan pertama tersebut mencapai tingkat keberhasilan 96\%. Pencapaian tersebut termasuk dalam kriteria sangat baik.
Pertemuan Kedua

Tabel 4. Hasil Pencapaian Daya Ingat Siswa Siklus I Pertemuan Kedua

\begin{tabular}{|c|c|c|c|c|}
\hline Nama & $\begin{array}{c}\text { Jumlah } \\
\text { Jawaban } \\
\text { Benar }\end{array}$ & Skor & Persentase & Kriteria \\
\hline Gl & 9 & 4 & $80 \%$ & Tinggi \\
\hline Va & 7 & 3 & $60 \%$ & Sedang \\
\hline $\mathrm{Ai}$ & 4 & 2 & $40 \%$ & Kurang \\
\hline Qi & 5 & 2 & $40 \%$ & Kurang \\
\hline $\mathrm{Ni}$ & 7 & 3 & $60 \%$ & Sedang \\
\hline $\mathrm{Na}$ & 7 & 3 & $60 \%$ & Sedang \\
\hline $\mathrm{Ca}$ & 4 & 2 & $40 \%$ & Kurang \\
\hline Sy & 4 & 2 & $40 \%$ & Kurang \\
\hline $\mathrm{Fa}$ & 5 & 2 & $40 \%$ & Kurang \\
\hline Jumlah & 52 & 23 & $51,1 \%$ & Cukup \\
\hline
\end{tabular}

Dari tabel di atas dapat diketahui rata-rata perolehan nilai evaluasi pada Subtema Peristiwa Kebangsaan Masa Penjajahan siswa kelas $\mathrm{V}$ siklus I pertemuan kedua yang dinilai dengan menggunakan rubrik penilaian daya ingat mencapai $51,1 \%$. Pencapaian tersebut termasuk dalam kriteria cukup.

Berdasarkan hasil observasi kegiatan mengajar guru pada siklus I pertemuan kedua, semua aspek kegiatan telah dilakukan oleh guru dalam pembelajaran. Berdasarkan hasil observasi kegiatan mengajar guru pertemuan kedua siklus I tersebut mencapai tingkat keberhasilan 100\%. Pencapaian tersebut termasuk dalam kriteria sangat baik. 
3. Siklus II

Pertemuan Pertama

Tabel 5. Hasil Pencapaian Daya Ingat Siswa Siklus II Pertemuan

Pertama

\begin{tabular}{|c|c|c|c|c|}
\hline Nama & $\begin{array}{c}\text { Jumlah } \\
\text { Jawaban } \\
\text { Benar }\end{array}$ & Skor & Persentase & Kriteria \\
\hline $\mathrm{Gl}$ & 9 & 4 & $80 \%$ & Tinggi \\
\hline $\mathrm{Va}$ & 8 & 4 & $80 \%$ & Tinggi \\
\hline $\mathrm{Ai}$ & 6 & 3 & $60 \%$ & Sedang \\
\hline $\mathrm{Qi}$ & 8 & 4 & $80 \%$ & Tinggi \\
\hline $\mathrm{Ni}$ & 9 & 4 & $80 \%$ & Tinggi \\
\hline $\mathrm{Na}$ & 8 & 4 & $80 \%$ & Tinggi \\
\hline $\mathrm{Ca}$ & 6 & 3 & $60 \%$ & Sedang \\
\hline $\mathrm{Sy}$ & 7 & 3 & $60 \%$ & Sedang \\
\hline $\mathrm{Fa}$ & 8 & 4 & $80 \%$ & Tinggi \\
\hline Jumlah & 69 & 33 & $73,3 \%$ & Baik \\
\hline
\end{tabular}

Dari tabel di atas dapat diketahui rata-rata perolehan nilai evaluasi pada Subtema Peristiwa Kebangsaan Masa Penjajahan siswa kelas V siklus II pertemuan pertama yang dinilai dengan menggunakan rubrik penilaian daya ingat mencapai 73,3\%. Pencapaian tersebut termasuk dalam kriteria baik.

Berdasarkan hasil observasi kegiatan mengajar guru pada siklus II pertemuan pertama, seluruh aspek kegiatan dilakukan oleh guru dalam pembelajaran. Berdasarkan hasil observasi kegiatan mengajar guru pertemuan pertama siklus II tersebut mencapai tingkat keberhasilan 100\%. Pencapaian tersebut termasuk dalam kriteria sangat baik.
Pertemuan Kedua

Tabel 6. Hasil Pencapaian Daya Ingat Siswa Siklus II Pertemuan Kedua

\begin{tabular}{|c|c|c|c|c|}
\hline Nama & $\begin{array}{c}\text { Jumlah } \\
\text { Jawaban } \\
\text { Benar }\end{array}$ & Skor & Persentase & Kriteria \\
\hline $\mathrm{Gl}$ & 10 & 5 & $100 \%$ & SangatTinggi \\
\hline $\mathrm{Va}$ & 10 & 5 & $100 \%$ & Sangat Tinggi \\
\hline $\mathrm{Ai}$ & 8 & 4 & $80 \%$ & Tinggi \\
\hline $\mathrm{Qi}$ & 9 & 4 & $80 \%$ & Tinggi \\
\hline $\mathrm{Ni}$ & 10 & 5 & $100 \%$ & Sangat Tinggi \\
\hline $\mathrm{Na}$ & 10 & 5 & $100 \%$ & Sangat Tinggi \\
\hline $\mathrm{Ca}$ & 8 & 4 & $80 \%$ & Tinggi \\
\hline $\mathrm{Sy}$ & 8 & 4 & $80 \%$ & Tinggi \\
\hline $\mathrm{Fa}$ & 8 & 4 & $80 \%$ & Tinggi \\
\hline Jumlah & 81 & 40 & $88,9 \%$ & Sangat Baik \\
\hline
\end{tabular}

Dari tabel di atas dapat diketahui rata-rata perolehan nilai evaluasi pada Subtema Peristiwa Kebangsaan Masa Penjajahan siswa kelas V siklus II pertemuan kedua yang dinilai dengan menggunakan rubrik penilaian daya ingat mencapai $88,9 \%$. Pencapaian tersebut termasuk dalam kriteria sangat baik.

Berdasarkan hasil observasi kegiatan mengajar guru pada siklus II pertemuan kedua, semua aspek kegiatan telah dilakukan oleh guru dalam pembelajaran. Berdasarkan hasil observasi kegiatan mengajar guru pertemuan kedua siklus II tersebut mencapai tingkat keberhasilan 100\%. Pencapaian tersebut termasuk dalam kriteria sangat baik.

Berdasarkan hasil pengamatan pada kondisi awal, terdapat permasalahan yaitu rendahnya daya ingat siswa pada subtema Peristiwa Kebangsaan Masa Penjajahan karena guru hanya menggunkan metode ceramah tanpa 
menggunakan model pembelajaran yang dapat meningkatkan daya ingat siswa terhadap suatu materi pembelajaran.

Setelah diberikan tindakan dengan menggunakan model pembelajaran take and give, terjadi peningkatan pada setiap pertemuan selanjutnya. Hasil pengamatan pada kondisi awal daya ingat siswa dengan siklus I kemudian siklus II mengalami peningkatan dan hasil telah memenuhi indikator keberhasilan tindakan.

Menurut M Shabir (2015:231) sebagai guru yang profesional harus memiliki keahlian khusus yang disebut kompetensi dalam menjalankan tugastugas profesionalnya. Keahlian tersebut meliputi kompetensi pedagogik, kompetensi kepribadian, kompetensi sosial dan kompetensi profesional. Menurut Susilowati, Susanto dan Daharti (2013:82) guru mempunyai tugas untuk mengarahkan kegiatan belajar siswa guna mencapai tujuan pembelajaran, oleh karena itu guru dituntut mampu menyampaikan bahan pembelajaran dengan baik. Ditambah dengan pendapat Ana (2020:51-52) yang menyatakan bahwa guru harus dapat menerapkan cara mengajar yang beragam dan dalam proses belajar mengajar, sehingga materi pelajaran dapat diterima siswa dengan optimal. Sedangkan menurut Afandi (2015:74) guru diharapkan mempunyai kemampuan pemahaman terhadap peserta didik, perencanaan dan pelaksanaan pembelajaran, evaluasi hasil belajar, dan pengembangan peserta didik untuk mengaktualisasikan berbagai potensi yang dimilikinya. Ditambah dengan pendapat Widyaningrum, Sondari dan Mulyati (2019:35) yang menyatakan bahwa peran guru tidak hanya sebagai penyampai ilmu melainkan juga berperan sebagai motor penggerak dan fasilitator dalam kegiatan belajar mengajar. Sedangkan Syaidah, Suyadi dan Ani (2018:186) menyatakan bahwa guru yang kompeten akan lebih mampu menciptakan lingkungan belajar yang efektif, menyenangkan dan lebih mampu mengelola kelas sehingga hasil belajar siswa juga baik. Menurut Armadi (2017:56) guru wajib merancang dan menyajikan pembelajaran yang aktif dan menyenangkan untuk mendorong peserta didik melakukan observasi, bertanya, bernalar, dan mengomunikasikan. Selain itu, seorang guru harus mampu menciptakan suasana belajar yang kondusif. Menurut Suswandari (2021:34) suasana belajar yang kondusif adalah suasana belajar dengan kenyamanan dan ketenangan.

Tugas seorang guru bukanlah tugas yang mudah, guru harus memahami karakteristik tiap siswa dengan melakukan pendekatanpendekatan kepada siswa. Dengan begitu guru dapat memahami dan mengenali karakter masing-masing siswa. Guru harus kreatif dalam menciptakan suasana belajar yang menyenangkan agar dapat menarik perhatian siswa. Untuk menciptakan suasana belajar yang menyenangkan guru dapat menggunakan model pembelajaran yang sesuai dengan kondisi siswa agar tujuan pembelajaran dapat tercapai secara maksimal. Menurut B Abdul (2019:144) model pembelajaran merupakan serangkaian kegiatan pembelajaran yang diimplementasikan oleh seorang guru yang didesain terlebih dahulu melalui pertimbangan-pertimbangan yang sudah 
matang sehingga dapat mempermudah pencapaian tujuan pembelajaran. Hal-hal yang mendukung adanya peningkatan daya ingat siswa di masa pandemi covid19 melalui penerapan model pembelajaran take and give dalam penelitian ini salah satunya yaitu guru sebagai sumber belajar. Guru dapat menjelaskan materi serta dapat menerapkan model pembelajaran take and give dengan baik, sehingga terjadi peningkatan pada daya ingat siswa.

Hasil pencapaian daya ingat siswa dan hasil pencapaian observasi kegiatan mengajar guru pra tindakan, siklus I, hingga Siklus II dapat dilihat dari tabel di bawah ini:

\section{Tabel 7. Hasil Pencapaian Daya Ingat Siswa dan Hasil Pencapaian Observasi Kegiatan Mengajar Guru pada Pra Tindakan, Siklus I dan Siklus} II

\begin{tabular}{|c|c|c|c|c|c|c|c|}
\hline \multirow{2}{*}{$\begin{array}{c}\text { Indikator } \\
\text { Keberhasilan }\end{array}$} & Pra & \multicolumn{3}{|c|}{ Siklus I } & \multicolumn{3}{c|}{ Siklus II } \\
\cline { 5 - 8 } & Siklus & P 1 & P 2 & $\begin{array}{c}\text { Rata- } \\
\text { rata }\end{array}$ & P 1 & P 2 & $\begin{array}{c}\text { Rata- } \\
\text { rata }\end{array}$ \\
\hline $\begin{array}{c}\text { Skor Rata-rata } \\
\text { Daya Ingat Siswa }\end{array}$ & 1,3 & 2,1 & 2,6 & 2,35 & 3,7 & 4,4 & 4,05 \\
\hline $\begin{array}{c}\text { Peningkatan Daya } \\
\text { Ingat Siswa } \\
\text { Mencapai 81-100\% }\end{array}$ & $26,7 \%$ & $42,2 \%$ & $51,1 \%$ & $\begin{array}{c}46,65 \\
\%\end{array}$ & $73,3 \%$ & $88,9 \%$ & $81,1 \%$ \\
\hline $\begin{array}{c}\text { Peningkatan Hasil } \\
\text { Observasi } \\
\text { Kegiatan Mengajar } \\
\text { Guru mencapai 81- } \\
\text { 100\% }\end{array}$ & $80 \%$ & $96 \%$ & $100 \%$ & $98 \%$ & $100 \%$ & $100 \%$ & $100 \%$ \\
\hline
\end{tabular}

Menurut Ardika dan Sardjana (2016:68) daya ingat dapat didefinisikan sebagai proses penyimpanan dan pemeliharaan informasi yang dilakukan dalam otak manusia yang telah diterima sebelumnya. Ditambah dengan pendapat Umainingsih, Alexon dan Kurniah (2017:90) yang menyatakan bahwa dalam tahap-tahap mekanisme daya ingat yang pertama adalah memasukkan informasi dalam hal ini diperoleh dengan belajar, kemudian menyimpan informasi tersebut dan menimbulkan kembali informasi yang telah diperoleh.

Dalam penelitian ini, daya ingat yang dimaksud adalah anak dapat menangkap informasi yang dijelaskan oleh guru serta informasi yang terdapat pada kartu materi, kemudian menyimpan informasi tersebut dalam otak, lalu menimbulkan kembali informasi yang telah didapat. Informasi yang ditimbulkan kembali berupa siswa dapat mengerjakan soal esai pada lembar evaluasi dengan benar.

Menurut Shaleh (Amaliah, 2011:27) terdapat beberapa upaya untuk meningkatkan kemampuan daya ingat, diantaranya:

a. Retrieval (pengulangan). Informasi yang diulang-ulang akan sering diingat. Untuk salah satu strategi mengingat kemampuan memori adalah mengulang-ulang kembali.

b. Informasi yang diingat harus mempunyai hubungan dengan hal lain, konteks (peristiwa, tempat, nama, perasaan tertentu) memegang peranan penting.

c. Mengorganisasi informasi sedemikian rupa sehingga dapat diingat kembali.

Dengan menerapkan model pembelajaran take and give siswa telah melakukan upaya untuk meningkatkan kemampuan daya ingat menurut pendapat Shaleh (Amaliah, 2011:27). Dengan menerapkan model pembelajaran take and give siswa memperoleh informasi secara berulang yaitu dari guru dan dari kartu materi take and give siswa lain, selain itu informasi yang terdapat pada kartu materi take and give mempunyai hubungan dengan peristiwa, tempat, nama, serta perasaan tertentu. Kemudian dengan penerapan model pembelajaran take and give siswa dapat mengorganisasi informasi yang 
diperoleh dari guru dan siswa lain sedemikian rupa sehingga dapat diingat kembali.

Pada penelitian ini model pembelajaran take and give dapat digunakan sebagai upaya meningkatkan daya ingat siswa di masa pandemi covid19 pada subtema Peristiwa Kebangsaan Masa Penjajahan kelas $V$ SD N Donotirto.

\section{KESIMPULAN}

Berdasarkan hasil penelitian dan pembahasan, dapat diambil kesimpulan bahwa penerapan model pembelajaran take and give dapat meningkatkan daya ingat siswa kelas $\mathrm{V}$ di masa pandemi covid-19 SD N Donotirto. Hasil penelitian menunjukkan bahwa terjadi peningkatan daya ingat sebanyak 19,95\% pada akhir siklus I dan pada akhir siklus II mengalami peningkatan sebanyak $34,45 \%$. Selain itu, terjadi peningkatan pada hasil observasi kegiatan mengajar guru sebanyak $18 \%$ pada akhir siklus I dan pada akhir siklus II mengalami peningkatan sebanyak $2 \%$. Peningkatan tersebut telah mencapai indikator keberhasilan, yaitu siswa dapat mengisi 8-10 soal esai pada pertemuan terakhir dengan benar serta mengalami peningkatan mencapai 81-100\% dengan kriteria sangat baik dan diperoleh hasil observasi kegiatan mengajar guru dengan peningkatan mencapai $81-100 \%$ dengan kriteria sangat baik.

Penerapan model pembelajaran take and give tersebut dapat membantu siswa untuk mengingat materi pada subtema Peristiwa Kebangsaan Masa Penjajahan. Karena dengan menerapkan model pembelajaran take and give siswa memperoleh informasi secara berulang yaitu dari guru dan dari kartu materi take and give siswa lain, selain itu informasi yang terdapat pada kartu materi take and give mempunyai hubungan dengan peristiwa, tempat, nama, serta perasaan tertentu. Kemudian dengan penerapan model pembelajaran take and give siswa dapat mengorganisasi informasi yang diperoleh dari guru dan siswa lain sedemikian rupa sehingga dapat diingat kembali.

Adapun saran dari peneliti yaitu sebaiknya guru lebih menguasai dalam pemilihan dan penggunaan model pembelajaran yang cocok untuk menyampaikan materi pembelajaran agar materi lebih mudah diterima oleh siswa.

\section{DAFTAR PUSTAKA}

Afandi, Muhamad. (2015). Kompetensi Guru Sebagai Kunci Keberhasilan dalam Pembelajaran Saintifik. Seminar Nasional Pendidikan, Universitas Muhammadiyah Purwokerto: Fakultas Keguruan dan IImu Pendidikan, Prodi PGSD.

Amaliah, Siti. (2011). Pengaruh Model Pembelajaran Kooperatif Tipe Take and Give Terhadap Retensi Siswa Dalam Tatanan IImiah Pada Konsep Jamur. Skripsi. Jakarta: Fakultas IImu Tarbiyah dan Keguruan Universitas Islam Negeri Syarif Hidayatullah. 
Ana, Ria Fajrin Rizqy. (2020). Persepsi Siswa Terhadap Keterampilan Mengajar Guru Menggunakan Media Visual. Autentik: Jurnal Pengembangan Pendidikan Dasar, 4(2), 50-65.

Armadi, Ali. (2017). Pendekatan Scientific dalam Pembelajaran Tematik Terpadu di SD. Jurnal Autentik, 1(1), 55-67.

Ardika, Y dan Sardjana, A. (2016). Efektivitas Metode Mnemonik Ditinjau dari Daya Ingat dan Hasil Belajar Matematika Siswa SMK Kelas X. Kreano Jurnal Matematika Kreatif-Inovatif, 7(1), 66-73.

B Abdul, Hamid. (2019).Urgensi Menciptakan Pembelajaran Yang Berkualitas Bagi Seorang Guru. Autentik: Jurnal Pengembangan Pendidikan Dasar, 3(2), 136147.

Fajri, Muhammad. (2018). Meneliti Itu Gampang: Mudah ber-PTK bagi Pendidik. Yogyakarta: Deepublish.

Fatoni, H dan Gularso, D. (2017). Efektivitas Model Pembelajaran Kooperatif Tipe Jigsaw Ditinjau dari Prestasi Belajar IPS Kelas V SD N Kasihan Bantul. Jurnal PGSD Indonesia, 3(2), 1-6.

Hartami, P., Abdullah, R., dan Safitri, Y. (2014). Penerapan Model Pembelajaran Kooperatif Tipe Take and Give Pada Materi Minyak Bumi di Kelas X MAN Sabang. Lantanida Journal, 2(2), 171-184.

Malawi, Ibadullah dkk. (2019). Teori dan Aplikasi Pembelajaran Terpadu. Jawa Timur: CV.AE Media Grafika.

M Shabir, U. (2015). Kedudukan Guru Sebagai Pendidik: (Tugas dan Tanggung Jawab, Hak dan Kewajiban, dan Kompetensi Guru). Auladuna, 2(2), 221-232.

Prihastin, Uchti. (2016). Penerapan Tipe Take and Give untuk Meningkatkan Aktivitas dan Hasil Belajar PKn Siswa Kelas V SDN 2 Sidodadi Pekalongan Lampung Timur. Skripsi. Bandar Lampung: Fakultas Keguruan dan IImu Pendidikan Universitas Lampung.

Susilowati, I., Susanto H, A, dan Daharti, R. (2013). Strategi Peningkatan Kompetensi Guru dengan Pendekatan Analysis Hierarchy Process. JEJAK Journal of Economics and Policy, 6(1), 80-92.

Suswandari, Meidawati. (2021). Implementasi Pembelajaran Tematik di SD N Kemasan 1 Polokarto. Autentik: Jurnal Pengembangan Pendidikan Dasar, 5(1), 33-46.

Syaidah, U., Suyadi, B, dan Ani H, M. (2018). Pengaruh Kompetensi Guru Terhadap Hasil Belajar Ekonomi di SMA Negeri Rambipuji Tahun Ajaran 2017/2018. Jurnal Pendidikan Ekonomi, 12(2), 185-191.

Umainingsih, M.B., Alexon, dan Kurniah, N. (2017). Penerapan Model Pembelajaran Memori untuk Meningkatkan Daya Ingat dan Prestasi Belajar Matematika. DIADIK:Jurnal IImiah Teknologi Pendidikan, 7(2), 87-97.

Undang-undang RI No. 20 tahun 2003. (2006). Sistem Pendidikan Nasional. Jakarta: Departemen Pendidikan Nasional RI.

Widyaningrum, W., Sondari, W, dan Mulyati. (2019). Meningkatkan Kompetensi Profesionalisme Guru di Abad 21 Melalui Pelatihan Pembelajaran Bahasa Inggris. Jurnal Pengabdian Masyarakat, 1(1), 35-44. 